\title{
Synthesis, Characterization, and Antimicrobial Activity of a Novel Trisazo Dye from 3-Amino-4H-thieno[3,4-c] [1] benzopyran-4-one
}

\author{
Joseph Tsemeugne, ${ }^{1,2}$ Emmanuel Sopbué Fondjo $\mathbb{D}{ }^{1}$ \\ Jean-de-Dieu Tamokou $\mathbb{D}^{3}{ }^{3}$ Taoufik Rohand, ${ }^{4}$ Arnaud Djintchui Ngongang, ${ }^{1}$ \\ Jules Roger Kuiate $\mathbb{D D}^{3}$ and Beibam Luc Sondengam ${ }^{2}$ \\ ${ }^{1}$ Laboratory of Applied Synthetic Organic Chemistry, Department of Chemistry, Faculty of Science, University of Dschang, \\ P.O. Box 67, Dschang, Cameroon \\ ${ }^{2}$ Department of Organic Chemistry, University of Yaoundé I, P.O. Box 812, Yaoundé, Cameroon \\ ${ }^{3}$ Laboratory of Microbiology and Antimicrobial Substances, Department of Biochemistry, Faculty of Science, University of Dschang, \\ P.O. Box 067, Dschang, Cameroon \\ ${ }^{4}$ Laboratory of Analytical and Molecular Chemistry, Polydisciplinary Faculty of Safi, Cadi Ayyad University, Route Sidi Bouzid, \\ BP 4162, 46000 Marrakech-Safi, Morocco
}

Correspondence should be addressed to Emmanuel Sopbué Fondjo; sopbue@yahoo.fr

Received 22 August 2017; Revised 18 October 2017; Accepted 22 November 2017; Published 1 February 2018

Academic Editor: Hussein El-Subbagh

Copyright (C) 2018 Joseph Tsemeugne et al. This is an open access article distributed under the Creative Commons Attribution License, which permits unrestricted use, distribution, and reproduction in any medium, provided the original work is properly cited.

\begin{abstract}
A new trisazo dye has been synthesized by coupling the diazonium ion of 3-amino-4H thieno[3,4-c][1]benzopyran-4-one with 2tert-butyl-4-methoxyphenol. The newly prepared trisazo dye was characterized by its physical, elemental, and spectroscopic data. 2D-NMR (COSY, HSQC, and HMBC) techniques were used to secure the structural assignments. The new trisazo dye (compound 7) along with precursors 3,4 , and 6 was screened by microdilution susceptibility assay for antibacterial and antifungal activities towards eight bacterial strains and three yeasts selected on the basis of their relevance as human pathogens. The results showed that compound 7 ( $\mathrm{MIC}=2-128 \mu \mathrm{g} / \mathrm{mL}$ ) was the most active as compared with its precursors. The most resistant microorganisms were $V$. cholerae NB2 and $V$. cholerae SG24, whereas the most sensitive microorganism was C. neoformans. The overall results of this study indicated that compound 7 had the greatest potential value against both yeasts and multidrug-resistant bacteria, so further investigation is warranted.
\end{abstract}

\section{Introduction}

The emergence of multidrug microbial resistance and the global warming are among the main challenges that the modern scientists have so far been facing in the recent decades. The fact that many pathogenic microorganisms responsible for several human and animal diseases have developed resistance mechanisms to the classical therapies has stimulated intensive investigations in the fields of natural and synthetic chemistry, with the aim of discovering new drug classes having much better therapeutic profiles. In this respect, the antimicrobial activities of numerous classes of organic substances such as phenols [1-3], coumarins [4-6], thiophenes [7-9], quinones [10,11], and azo compounds [1214] are currently the targets of the worldwide drug discovery efforts.

Interestingly, we are now seeing the emergence of a new generation of drugs with hybrid molecular architectures combining the biological features of two or more small molecules or even small molecules and biologics. The expectation is that, in the long term, such molecular and/or biologic conjugates could become a dominant form of targeted infectious diseases' therapies.

The idea of combining two or more potentially bioactive substructures to make an integrated new molecular framework with a higher anticipated therapeutic firepower 
is conceptually simple yet highly successful in the context of infectious diseases that require effective killing of the microbes.

The less use of azo compounds in medicinal chemistry is due to the fact that, in the presence of the enzymes of the organism, these compounds are readily reduced to aromatic amines which are reported to be highly mutagenic and carcinogenic [15], justifying therefore their marginal antimicrobial activities [16]. Nevertheless, it has been found that increasing the number of this group in the same compound results in the gradual inhibition of the biodegradation process. Hence, because of the low biodegradation rate of the polyazo compounds due to the important number of the $-\mathrm{N}=\mathrm{N}-$ fragments in their structures, they should be preferred to their mono and disazo counterparts in the inhibition of the main pathogenic microorganisms of humans [17]. Moreover, previous studies have established the cumulative and synergetic effects of this functional group in the improvement of the biological activities of several hybrid lead compounds [18].

In this work, we report for the first time the synthesis of a new trisazo dye from 3-amino- $4 \mathrm{H}$-thieno[3,4c][1]benzopyran-4-one and 2-tert-butyl-4-methoxyphenol, for further investigations in drug development against multidrug-resistant bacteria and fungi. We carried out the antimicrobial screenings of the new compound on eight bacterial strains (among which $V$. cholerae NB2, V. cholerae SG24, V. cholerae CO6, and S. flexneri are well known resistant strains) and three pathogen yeasts.

\section{Experimental}

\subsection{Materials and Methods}

2.1.1. General Information. Melting point is corrected and was determined with an Electrothermal Melting Point Apparatus, model 9100. The TLC was carried out on Eastman Chromatogram Silica Gel Sheets $(13181 ; 6060)$ with a fluorescent indicator. A mixture of ethyl acetate and methylene chloride $(7: 3)$ was used as an eluent and iodine was used as a revelator for the chromatograms. The IR spectra were measured with a Fourier Transform Infrared spectrometer JASCO FT/IR4100. The UV spectrum was recorded with a Beckman DU640 Spectrophotometer. Combustion analyses were carried out with a $\mathrm{C}, \mathrm{H}, \mathrm{N}$, and S Euro EA from HEKAtech company, and results were found to be in good agreement $( \pm 0.3 \%)$ with the calculated values. EIMS were measured on Mass Spectrometer LCQ Classic with ESI Source from Thermo Fisher Scientific company. ${ }^{1} \mathrm{H}-\mathrm{NMR}$ spectrum was recorded in $\mathrm{DMSO}-d_{6}$ with a $250 \mathrm{MHz}$ spectrometer Bruker AV III. ${ }^{13} \mathrm{C}-\mathrm{NMR}$ spectrum was recorded in DMSO- $d_{6}$ with a 62.5 MHz spectrometer Bruker AV III. TMS was used as an internal reference.

2.1.2. Preparation of the Reagents and Starting Materials. All the reagents mentioned in this work were purchased from Aldrich and Fluka and were used without further purification.

Starting material 4 was prepared according to the procedures mentioned in the literature published earlier [19].
A mixture of $4.65 \mathrm{~g}$ of 4-methyl-2-oxo-2H-[1]benzopyran3 -carbonitrile (3) and sulphur (1.22 g, in excess) in ethanol $(30 \mathrm{ml})$ was stirred using a magnetic plate shaker thermostated at $45^{\circ} \mathrm{C}$. Ammonia $(6 \mathrm{ml})$ was added dropwise during the first $10 \mathrm{~min}$ of the reaction. After $7 \mathrm{~h}$ of reaction, the resulting precipitate $(5.08 \mathrm{~g}, 93 \%)$ was collected by filtration, washed with distilled water, and recrystallised in benzene to yield a yellow powder. m.p. 195-196 ${ }^{\circ} \mathrm{C}$ (Lit. [19], 198-199 ${ }^{\circ} \mathrm{C}$, from benzene). IR $\left(\mathrm{KBr}, \mathrm{cm}^{-1}\right) v_{\max }: 3449\left(-\mathrm{NH}_{2}\right) ; 1687$ $(\mathrm{C}=\mathrm{O}) ; 1603$ and $1547(\mathrm{C}=\mathrm{C}) ; 1224(\mathrm{C}-\mathrm{O}) \mathrm{cm}^{-1} \cdot{ }^{1} \mathrm{H}$ NMR (250 MHz, DMSO- $\left.d_{6}, \mathrm{Me}_{4} \mathrm{Si}, \delta, \mathrm{ppm}\right): 7.87$ (dd, $1 \mathrm{H}, J=8.0$ and $1.5 \mathrm{~Hz}, \mathrm{H}-8$ ), 7.78 (br s, $2 \mathrm{H}, \mathrm{NH}_{2}$ ); 7.36 (ddd, $1 \mathrm{H}, J=8.0$, 7.4 and $1.8 \mathrm{~Hz}, \mathrm{H}-6), 7.22-7.17$ (m, 2H, H-7 and H-5), 6.89 (s, $1 \mathrm{H}$, thiophenic $\mathrm{H}) .{ }^{13} \mathrm{C} \mathrm{NMR}\left(62.5 \mathrm{MHz}, \mathrm{DMSO}-d_{6}, \mathrm{Me}_{4} \mathrm{Si}\right.$, $\delta, \mathrm{ppm}): 166.70$ (C-3), 158.98 (C-2), 151 (C-4a), 130.90 (C8a), 129.26 (C-9), 124.39 (C-6), 123.91 (C-8), 118.05 (C-2a), 117.09 (C-7), 98.07 (C-8b), 97.54 (C-5); m/z (EI) 217 (M+; $100 \%)$. Elemental Analysis: $\mathrm{C}_{11} \mathrm{H}_{7} \mathrm{NO}_{2}$ S. Calculated: C: 60.83; H, 3.23; N, 6.45; S, 14.75. Found: C, 61.17; H, 3.36; N, 6.49; S, 14.45 .

2.1.3. Preparation of Diazonium Salt Solution. In a similar manner as described in [20], dry sodium nitrite $(2.07 \mathrm{~g}$, $3 \mathrm{mmol}$ ) was slowly added over a period of 30 minutes to concentrated sulphuric acid $(10 \mathrm{~mL})$ with occasional stirring. The solution was cooled to $0-5^{\circ} \mathrm{C}$. Compound 4 was dissolved in DMSO $(10 \mathrm{~mL})$ and cooled to $0-5^{\circ} \mathrm{C}$. The nitrosylsulfuric acid solution was added to the solution of $\mathbf{4}$ and the temperature was maintained between 0 and $5^{\circ} \mathrm{C}$. The clear diazonium salt solution thus obtained consisting of the in situ formed intermediate 5 was used immediately in the coupling reaction.

2.1.4. 3-(2-\{3-(tert-Butyl)-2-hydroxy-5-methoxy-4,6-bis[2-(4oxo-4H-thieno[3,4-c]chromen-3-yl)diazenyl]phenyl $\}$ diazenyl)-4H-thieno[3,4-c]chromen-4-one Pentahydrate (7). The phenol derivative 2-tert-butyl-4-methoxyphenol (540 mg; 3 $\mathrm{mmol})$ was dissolved in DMSO $(10 \mathrm{~mL})$ and then cooled in an ice bath at $0-5^{\circ} \mathrm{C}$. The diazonium solution of 4 previously prepared was added dropwise over 1 hour, and then $15 \mathrm{~mL}$ of sodium acetate solution (10\%) was added to the mixture. The $\mathrm{pH}$ of the mixtures was in the range 9-11. The solid precipitate was collected on a filter and crystallised from methanol to give the title 7 (632 mg; 49\%) as a green powder. m.p. $200^{\circ} \mathrm{C}$. IR $\left(\mathrm{KBr}, \mathrm{cm}^{-1}\right) v_{\max }: 3260(\mathrm{OH}), 3073$ (Ar. C-H), $1721(\mathrm{C}=\mathrm{O}), 1677$ (Ar C=C), 1483, $1435(\mathrm{~N}=\mathrm{N}) \mathrm{cm}^{-1}$. UV (THF) $\lambda_{\max } / \mathrm{nm}(\log \varepsilon): 215$ (2.95), 240 (4.56), 268 (4.18), 325.5 (4.74), 381 (4.48). ${ }^{1} \mathrm{H}$ NMR (250 MHz, DMSO- $d_{6}$, $\left.\mathrm{Me}_{4} \mathrm{Si}, \delta, \mathrm{ppm}\right): 9.18$ (d, $\left.1 \mathrm{H}, J=9.75 \mathrm{~Hz}, 9-\mathrm{H}\right), 9.01(\mathrm{~d}, 1 \mathrm{H}, J$ $\left.=10.5 \mathrm{~Hz}, 9^{\prime \prime}-\mathrm{H}\right), 8.83\left(\mathrm{~d}, 1 \mathrm{H}, J=10.5 \mathrm{~Hz}, 9^{\prime \prime \prime}-\mathrm{H}\right), 8.59(\mathrm{dd}$, $1 \mathrm{H}, J=9.0$ and $\left.7.8 \mathrm{~Hz}, 8^{\prime \prime}-\mathrm{H}\right), 8.46(\mathrm{dd}, 1 \mathrm{H}, J=10.5$ and $\left.9.75 \mathrm{~Hz}, 8^{\prime \prime \prime}-\mathrm{H}\right), 8.32(\mathrm{dd}, 1 \mathrm{H}, J=9.75$ and $9.75 \mathrm{~Hz}, 8-\mathrm{H})$, $8.27\left(\mathrm{dd}, 1 \mathrm{H}, J=9.75\right.$ and $\left.9.75 \mathrm{~Hz}, 7^{\prime \prime}-\mathrm{H}\right), 8.15(\mathrm{dd}, 1 \mathrm{H}, J=$ 9.75 and $\left.9.0 \mathrm{~Hz}, 7^{\prime \prime \prime}-\mathrm{H}\right), 8.06(\mathrm{dd}, 1 \mathrm{H}, J=11.25$ and $9.0 \mathrm{~Hz}$, $7-\mathrm{H}), 7.99(\mathrm{~d}, 1 \mathrm{H}, J=9.0 \mathrm{~Hz}, 6-\mathrm{H}), 7.97(\mathrm{~d}, 1 \mathrm{H}, J=9.6 \mathrm{~Hz}$, $\left.6^{\prime \prime}-\mathrm{H}\right), 7.96\left(\mathrm{~d}, 1 \mathrm{H}, J=7.0 \mathrm{~Hz}, 6^{\prime \prime \prime}-\mathrm{H}\right), 7.67$ (s, 1H, 1-H), 7.58 $\left(\mathrm{s}, 1 \mathrm{H}, 1^{\prime \prime \prime}-\mathrm{H}\right), 7.50\left(\mathrm{~s}, 1 \mathrm{H}, 1^{\prime \prime}-\mathrm{H}\right), 3.92\left(\mathrm{~s}, 10 \mathrm{H}, \mathrm{H}_{2} \mathrm{O}\right), 3.90(\mathrm{~s}$, $1 \mathrm{H}, \mathrm{OH}), 3.50\left(\mathrm{~s}, 3 \mathrm{H}, \mathrm{OCH}_{3}\right), 1.54\left(\mathrm{~s}, 9 \mathrm{H}, \mathrm{CH}_{3}\right) \cdot{ }^{13} \mathrm{C} \mathrm{NMR}$ (62.5 MHz, DMSO- $d_{6}, \mathrm{Me}_{4} \mathrm{Si}, \delta, \mathrm{ppm}$ ): 164.9 (C-4), 164.2 


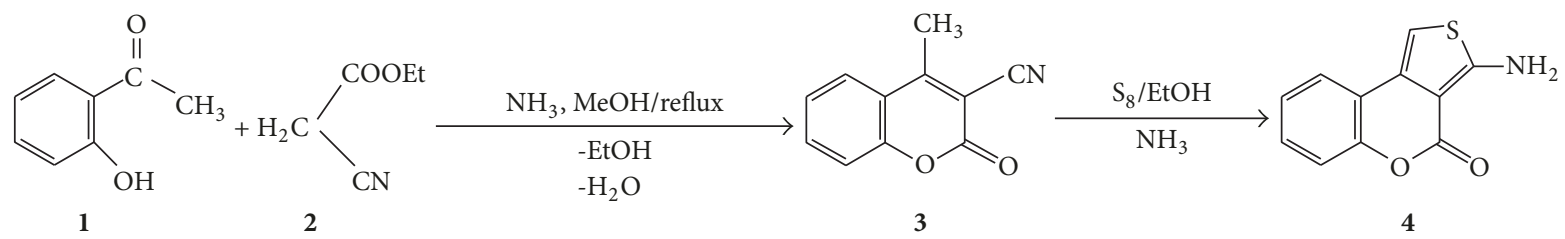

Scheme 1: Reaction sequences to compound 4.

(C-4 $4^{\prime \prime}$ and $\left.\mathrm{C}-4^{\prime \prime \prime}\right), 157.3\left(\mathrm{C}-9 \mathrm{~b}^{\prime \prime}\right.$ and $\left.\mathrm{C}-9 \mathrm{~b}^{\prime \prime \prime}\right), 157.2(\mathrm{C}-9 \mathrm{~b})$, $155.4\left(\mathrm{C}-5 \mathrm{a}^{\prime \prime}\right), 155.3\left(\mathrm{C}-5 \mathrm{a}^{\prime \prime \prime}\right), 154.5(\mathrm{C}-5 \mathrm{a}), 154.3\left(\mathrm{C}-3 \mathrm{a}^{\prime \prime}\right)$, $154.0\left(\mathrm{C}-3 \mathrm{a}^{\prime \prime \prime}\right), 153.2$ (C-3a), $148.3\left(\mathrm{C}-2^{\prime}\right), 138.2\left(\mathrm{C}-5^{\prime}\right), 136.0$ (C-3), $135.8\left(\mathrm{C}-3^{\prime \prime \prime}\right), 134.9\left(\mathrm{C}-3^{\prime \prime}\right), 131.6(\mathrm{C}-9 \mathrm{a}), 130.5\left(\mathrm{C}-9 \mathrm{a}^{\prime \prime}\right)$, $129.7\left(\mathrm{C}-9 \mathrm{a}^{\prime \prime \prime}\right), 129.6(\mathrm{C}-7), 129.4\left(\mathrm{C}-7^{\prime \prime}\right), 129.1\left(\mathrm{C}-7^{\prime \prime \prime}\right), 127.6$ $\left(\mathrm{C}-9^{\prime \prime}\right.$ and C-9 $\left.{ }^{\prime \prime \prime}\right), 126.8$ (C-9), $126.0(\mathrm{C}-8), 125.9\left(\mathrm{C}-8^{\prime \prime \prime}\right)$, $125.8\left(\mathrm{C}-8^{\prime \prime}\right), 120.5\left(\mathrm{C}-6^{\prime}\right), 118.6\left(\mathrm{C}-4^{\prime}\right), 117.7$ (C-6), 117.5 $\left(\mathrm{C}-6^{\prime \prime}\right), 117.6\left(\mathrm{C}-6^{\prime \prime \prime}\right), 115.4\left(\mathrm{C}-1^{\prime \prime \prime}\right), 115.3\left(\mathrm{C}-1^{\prime \prime}\right), 114.7(\mathrm{C}-1)$, $113.8\left(\mathrm{C}-1^{\prime}\right), 101.8\left(\mathrm{C}-3^{\prime}\right), 56.7\left(\mathrm{OCH}_{3}\right), 25.5\left(\mathrm{C}\left(\mathrm{CH}_{3}\right)_{3}\right), 18.7$ $\left(3 \mathrm{CH}_{3}\right) \cdot \mathrm{m} / z(\mathrm{EI}): 957(1)\left[\mathrm{M}^{+\bullet}+2 \mathrm{H}\right], 525(1), 516(2), 459$ (21), 393 (3), 338 (5), 279 (1), 247 (19), 230 (6). Elemental Analysis: $\mathrm{C}_{44} \mathrm{H}_{38} \mathrm{~N}_{6} \mathrm{O}_{13} \mathrm{~S}_{3}$ Calculated: C, 55.34; $\mathrm{H}, 4.01 ; \mathrm{N}$, 8.80; S, 10.07. Found: C, 55.36; H, 3.99; N, 8.78; S, 9.99.

\subsection{Antimicrobial Assay}

2.2.1. Microorganisms. A total of eight bacteria and three yeasts were tested for their susceptibility to the studied compounds. The microorganisms used in this study were taken from our laboratory collection. Among the clinical strains of Vibrio cholerae used in this study, strains NB2 and SG24 (1) belonged to $\mathrm{O} 1$ and $\mathrm{O} 139$ serotypes, respectively. These strains were able to produce cholera toxin and hemolysin [21, 22]. The other microbial species used in this study were Candida parapsilosis ATCC22019, Candida albicans ATCC9002, Cryptococcus neoformans IP95026, Bacillus subtilis, Escherichia coli S2 (1), Vibrio cholerae non-O1 and non-O139 (strains CO6 and PC2), and Shigella flexneri. The V. cholerae non-O1 and non-O139 strains were positive for hemolysin production but negative for cholera toxin production [22]. The bacterial and fungal species were grown at $37^{\circ} \mathrm{C}$ and maintained on nutrient agar (NA, Conda, Madrid, Spain) and Sabouraud Dextrose Agar (SDA, Conda) slants, respectively.

\subsubsection{Determination of Minimum Inhibitory Concentration} (MIC) and Minimum Microbicidal Concentration (MMC). The antimicrobial activity was investigated by determining the minimum inhibitory concentrations (MICs), minimum bactericidal concentrations (MBCs), and minimum fungicidal concentrations (MFCs). MIC of compounds was assessed using the broth microdilution method [23]. Each test compound was dissolved in dimethylsulfoxide (DMSO, Fisher Chemicals) to give a stock solution. This was serially diluted twofold in Mueller-Hinton Broth (MHB) for bacteria and Sabouraud Dextrose Broth (SDB) for fungi to obtain a concentration range of 512 to $0.25 \mu \mathrm{g} / \mathrm{ml}$. One hundred microliters of each concentration was introduced into a well (96-well microplate) containing $90 \mu \mathrm{l}$ of SDB or MHB, and $10 \mu \mathrm{l}$ of inoculum $\left(1 \times 10^{6} \mathrm{CFU} / \mathrm{mL}\right.$ for bacteria and $1 \times 10^{5}$ spores $/ \mathrm{ml}$ for yeasts) was added to obtain a final concentration range of 256 to $0.125 \mu \mathrm{g} / \mathrm{ml}$. Plates were covered and incubated on the shaker at $37^{\circ} \mathrm{C}$ for $24 \mathrm{~h}$ (bacteria), $48 \mathrm{~h}$ (Candida spp.), and $72 \mathrm{~h}$ (Cryptococcus). MICs were assessed visually after the corresponding incubation period and were taken as the lowest sample concentration at which there was no growth or virtually no growth.

For the minimum microbicidal concentration (MMC) determination, $10 \mu \mathrm{l}$ aliquots from each well that showed no growth of microorganism were plated on Mueller-Hinton Agar or Sabouraud Dextrose Agar and incubated at $37^{\circ} \mathrm{C}$ for $24 \mathrm{~h}$ (bacteria), $48 \mathrm{~h}$ (Candida spp.), and $72 \mathrm{~h}$ (Cryptococcus). The lowest concentration that yielded no growth after the subculturing was taken as the MBCs or MFCs. Ciprofloxacin (Sigma-Aldrich, Steinheim, Germany) for bacteria and nystatin (Sigma-Aldrich, Steinheim, Germany) for yeasts were used as positive controls, while broth with $20 \mu \mathrm{L}$ of DMSO was used as a negative control. The assay was repeated thrice.

\section{Results and Discussion}

3.1. Chemistry. The title 2-aminothiophene reagent 4 was prepared in excellent yield by applying the third version of the Gewald methodology (Scheme 1) as previously reported [19, 24-26].

The in situ formed intermediate thienyl diazonium sulphate 5 (Scheme 2) was generated from the diazotization of compound 4 using nitrosylsulfuric acid at a very low temperature $\left(0-5^{\circ} \mathrm{C}\right)$. The freshly prepared diazonium solution was then coupled with phenolic reagent 2-tert-butyl-4methoxyphenol $\mathbf{6}$. The resulting mixture was worked up as usual to yield the azo compound 7 (Scheme 2).

The structure of the newly synthesized compound 7 was elucidated by IR, UV, NMR, mass spectral studies, and elemental analysis.

The IR spectrum of compound 7 showed absorption bands ranging between 3260 and $2324 \mathrm{~cm}^{-1}$ due to the stretching vibration of $\mathrm{OH}$ of phenol and $\mathrm{H}_{2} \mathrm{O}$ molecules. Around $1721 \mathrm{~cm}^{-1}$ appeared a band of stretching frequencies of the carbonyl functionality, whereas the characteristic stretching frequencies of the $-\mathrm{N}=\mathrm{N}$ - linkages were exhibited around $1435 \mathrm{~cm}^{-1}$. The absorption bands at $1677 \mathrm{~cm}^{-1}$ and $763 \mathrm{~cm}^{-1}$ depicted the presence of $\mathrm{C}=\mathrm{C}$ and $\mathrm{Ar}-\mathrm{H}$, respectively. The infrared spectra also showed a distinctive band at $1051 \mathrm{~cm}^{-1}$ due to $\mathrm{C}-\mathrm{O}$ bond of the methoxy group.

The electronic transitions of the UV-visible spectra in DMSO give rise to wavelength $\lambda_{\max }$ ranging from 215 to $381 \mathrm{~nm}$ as a result of $\pi \rightarrow \pi^{*}$ transitions of the compound indicating the presence of an extended $\pi$-conjugation of the $\mathrm{C}=\mathrm{C}$ backbone enhanced by the $\mathrm{N}=\mathrm{N}$ bridges linking the three thienocoumarins moieties to the parent phenolic 


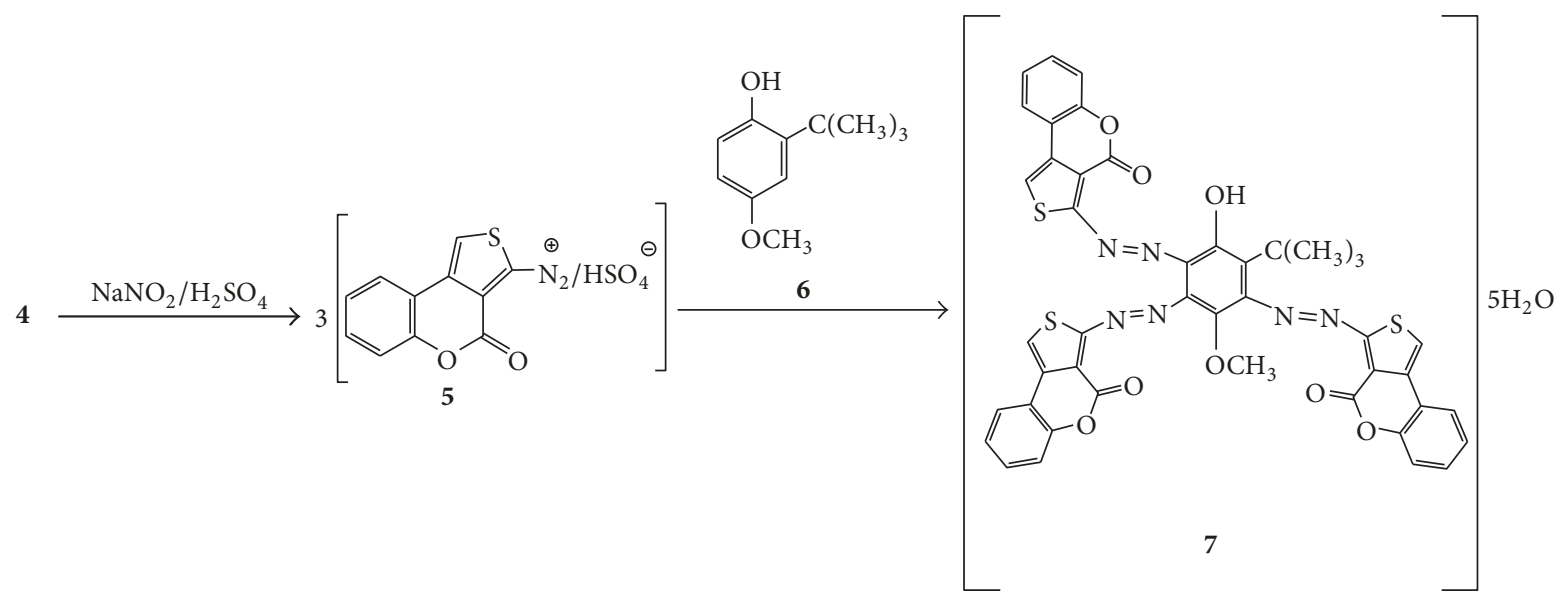

SCHEME 2: Reaction sequences to compound 7.

benzene ring. Five strong absorption bands were observed, whereby those appearing at $\lambda_{\max } 215 \mathrm{~nm}(\log \varepsilon=2.95)$ and $\lambda_{\max } 240 \mathrm{~nm}(\log \varepsilon=4.56)$ may be attributed to $\pi \rightarrow \pi^{*}$ transition of the benzenoid moiety of the compounds and intraligand $\pi \rightarrow \pi^{*}$ transition. The third and fourth bands located at $\lambda_{\max } 268 \mathrm{~nm}(\log \varepsilon=4.18)$ and $\lambda_{\max } 325.5 \mathrm{~nm}$ $(\log \varepsilon=4.74)$ were attributed to the electronic $n \rightarrow \pi^{*}$ transitions of the $-\mathrm{N}=\mathrm{N}-$ group. The last band appearing in the visible region around $\lambda_{\max } 381 \mathrm{~nm}(\log \varepsilon=4.48)$ is probably related to a transition involving the whole electronic system of the azo dyes.

The structure of compound 7 is further strongly supported by its elemental analysis and its HREIMS, which showed a molecular ion peak at $m / z$ 955. The mass spectrum of compound 7 exhibited fragment ions at $m / z$ 910, 865, and 847 which could be assigned to $\left[\mathrm{M}^{+\bullet}-\mathrm{COOH}\right],\left[\mathrm{M}^{+\bullet}\right.$ $\left.5 \mathrm{H}_{2} \mathrm{O}\right]$, and $\left[\mathrm{M}^{+\bullet}-6 \mathrm{H}_{2} \mathrm{O}\right]$, respectively. The ion fragments at $m / z=663,616$, and 230 were assigned as in Scheme 3, confirming the above structural hypothesis.

On the ${ }^{1} \mathrm{H}$-NMR spectrum, the singlets observed at $\delta_{\mathrm{H}}=$ 3.50 and $1.54 \mathrm{ppm}$ were, respectively, assigned to the protons of the methoxy group and the protons of the 3 methyl substituents of the tert-butyl group. The thiophenic protons resonated at $\delta_{\mathrm{H}}=7.67,7.50$, and $7.58 \mathrm{ppm}$ as a singlet, while the singlets observed at $\delta_{\mathrm{H}}=9.04 \mathrm{ppm}$ were assigned to the $\mathrm{OH}$ group. The ${ }^{1} \mathrm{H}-\mathrm{NMR}$ also showed a set of three couples of poorly resolved "ddd"-signals [centered at 8.06 $(\mathrm{H}-7, J=11.25$ and $9.0 \mathrm{~Hz}), 8.32(\mathrm{H}-8, J=9.75$ and $9.75 \mathrm{~Hz})$, $8.27\left(\mathrm{H}-7^{\prime \prime}, J=9.75\right.$ and $\left.9.75 \mathrm{~Hz}\right), 8.59\left(\mathrm{H}-8^{\prime \prime}, J=9.0\right.$ and $7.8 \mathrm{~Hz}), 8.15\left(\mathrm{H}-7^{\prime \prime \prime}, J=9.75\right.$ and $\left.9.0 \mathrm{~Hz}\right)$, and $8.46(\mathrm{H}-$ $8^{\prime \prime \prime}, J=10.5$ and $\left.\left.9.75 \mathrm{~Hz}\right), \mathrm{ppm}\right]$ and a set of three couples of poorly resolved "dd"-signals [centered at $7.99(\mathrm{H}-6, J=$ $9.0 \mathrm{~Hz}), 9.18(\mathrm{H}-9, J=9.75 \mathrm{~Hz}), 7.97\left(\mathrm{H}-6^{\prime \prime}, J=9.6 \mathrm{~Hz}\right), 9.01$ $\left(\mathrm{H}-9^{\prime \prime}, J=10.5 \mathrm{~Hz}\right), 7.96\left(\mathrm{H}-6^{\prime \prime \prime}, J=7.0 \mathrm{~Hz}\right)$, and $8.83(\mathrm{H}-$ $\left.\left.9^{\prime \prime \prime}, J=10.5 \mathrm{~Hz}\right)\right]$ overlapping in the range $7.97-9.18 \mathrm{ppm}$, which were attributed to the protons of the three thienocoumarin substructural units of the coupling product. The ${ }^{1} \mathrm{H}-{ }^{1} \mathrm{H}$-COSY experiment was advantageously used in the accurate assignments of the different ${ }^{1} \mathrm{H}^{-1} \mathrm{H}$ connectivities [27].
The ${ }^{13} \mathrm{C}$-NMR spectrum of compound 7 displayed forty carbon signals instead of forty-four as required by the molecular formula. This could be explained by the overlapping of the signals of the three methyl substituents of the tert-butyl group at $\delta_{\mathrm{C}} 18.72 \mathrm{ppm}$ due to their magnetic and chemical equivalence. Furthermore, it was assumed that the signals of two of the three carbonyl functionalities overlapped to give the intense signal at $\delta_{\mathrm{C}} 164.17 \mathrm{ppm}$ besides the signal at $\delta_{\mathrm{C}} 164.94 \mathrm{ppm}$ assigned to the other carbonyl group. A close inspection of the 3D view (Figure 2) of the optimized structure geometry of compound 7 clearly reveals that the electron clouds of the carbonyl groups of the two 3-diazenyl$4 \mathrm{H}$-thieno[3,4-c]chromen-4-one moieties attached at positions -3 and -5 of the central phenolic ring are virtually more involved in the interactions with the electron clouds of the neighboring atoms and groups than the carbonyl group of the 3-diazenyl-4H-thieno[3,4-c]chromen-4-one moiety fixed at position -2 of the core phenolic ring. These observations could justify the slight upfield shifts $(\Delta \delta=166.70-164.17=$ $2.53 \mathrm{ppm}$ for the two overlapping carbonyl groups and $\Delta \delta=$ $166.70-164.94=1.76 \mathrm{ppm}$ for the other one) that occurred in the resonances of the three carbonyl functions when compared to the chemical shift $\left(\delta_{\mathrm{C}}=166.70 \mathrm{ppm}\right)$ of the corresponding carbonyl group in the starting compound 4. Based on the DEPT-90/135 experiments, the remaining signals were assigned without ambiguity to the aromatic $\mathrm{C}$ atoms bearing hydrogen atoms. The HMBC experiments [27] were used to disclose the two-bond $\left({ }^{2} J_{\mathrm{CH}}\right)$, threebond $\left({ }^{3} J_{\mathrm{CH}}\right)$, and occasionally four-bond $\left({ }^{4} J_{\mathrm{CH}}\right)$ couplings (Table 1 and Figure 1) between the hydrogen atoms and the tertiary and quaternary carbon atoms, thereby facilitating their identification and their assignments.

3.2. Antimicrobial Activity. The antimicrobial activity of new trisazo dye along with some of its precursors was examined by microdilution susceptibility assay against eight bacterial strains and three yeasts selected on the basis of their relevance as human pathogens. The results showed that the tested compounds exhibited variable MICs (2 to $256 \mu \mathrm{g} / \mathrm{mL}$ ) depending on the microbial strains (Table 2). The most resistant microorganisms were $V$. cholerae NB2 and 


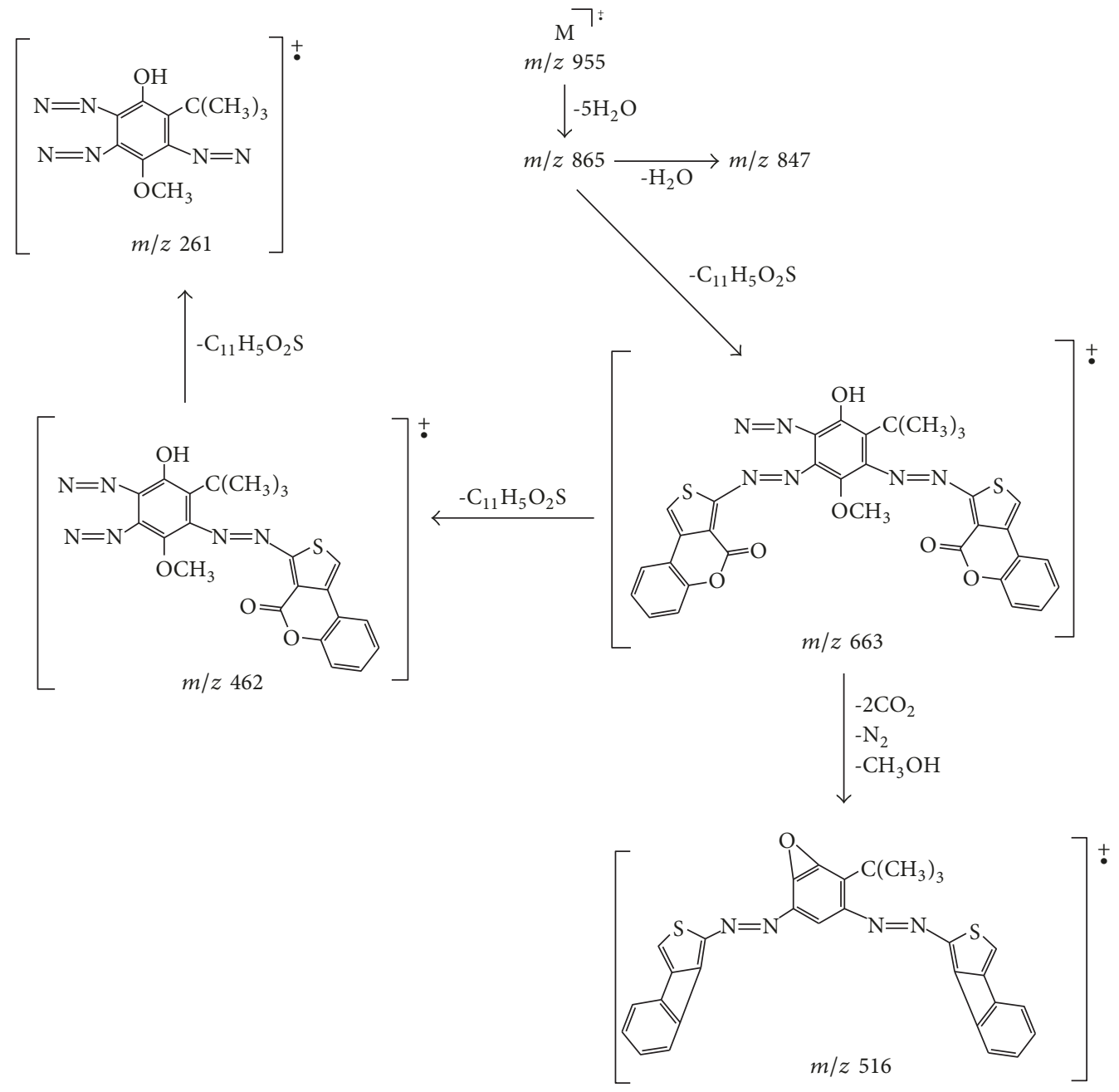

SCHEME 3: Significant HRMS fragmentation patterns of compound 7.

TABLE 1: Important HMBC interactions in compound $7 ;{ }^{1} \mathrm{H}$ and ${ }^{13} \mathrm{C}$ chemical shifts $(\delta / \mathrm{ppm})$ in DMSO- $d_{6}$ as the solvent $\left(25^{\circ} \mathrm{C}\right)$.

\begin{tabular}{|c|c|c|c|c|c|}
\hline \multicolumn{3}{|c|}{ Compound 7} & \multicolumn{3}{|c|}{ Compound 7} \\
\hline $\mathrm{C}$ atom & $\delta^{13} \mathrm{C}$ & $\operatorname{HMBC}(\mathrm{H} \rightarrow \mathrm{C})$ & $\mathrm{C}$ atom & $\delta^{13} \mathrm{C}$ & $\operatorname{HMBC}(\mathrm{H} \rightarrow \mathrm{C})$ \\
\hline 7 & 129.6 & H-8 (8.32) & $9 a^{\prime \prime}$ & 130.5 & H-8 ${ }^{\prime \prime}$ (8.59), H-7" (8.27), H-6" (7.97) \\
\hline 9 & 126.8 & H-1 (7.67) & $1^{\prime \prime \prime}$ & 115.4 & $\mathrm{H}-9^{\prime \prime \prime}(8.83), \mathrm{H}-1^{\prime \prime \prime}(7.58)$ \\
\hline $9 a$ & 131.6 & $\mathrm{H}-1(7.67)$ & $3^{\prime \prime \prime}$ & 135.8 & H-9 $9^{\prime \prime \prime}$ (8.83), H-7"' (8.15), H-1"' (7.58) \\
\hline $9 b$ & 157.2 & H-8 (8.32), H-6 (7.99) & $4^{\prime \prime \prime}$ & 164.2 & $\mathrm{H}-7^{\prime \prime \prime}(8.15)$ \\
\hline $1^{\prime \prime}$ & 115.3 & $\mathrm{H}-1^{\prime \prime}(7.50)$ & $5 a^{\prime \prime \prime}$ & 155.3 & $\mathrm{H}-9^{\prime \prime \prime}$ (8.83), H-7 $7^{\prime \prime \prime}(8.15)$ \\
\hline $5 a^{\prime \prime}$ & 155.4 & $\mathrm{H}-6^{\prime \prime}(7.97)$ & $6^{\prime \prime \prime}$ & 117.6 & $\mathrm{H}-\mathrm{7}^{\prime \prime \prime}(8.15)$ \\
\hline $7^{\prime \prime}$ & 129.4 & H-9" (9.01), H-6" (7.97) & $9^{\prime \prime \prime}$ & 127.6 & $\mathrm{H}-8^{\prime \prime \prime}(8.46), \mathrm{H}-1^{\prime \prime \prime}(7.58)$ \\
\hline $8^{\prime \prime}$ & 125.8 & $\mathrm{H}-8^{\prime \prime}(8.59)$ & $9 a^{\prime \prime \prime}$ & 129.7 & $\mathrm{H}-\mathrm{1}^{\prime \prime \prime}(7.58)$ \\
\hline $9^{\prime \prime}$ & 127.6 & H-1" $(7.50)$ & & & \\
\hline
\end{tabular}

$V$. cholerae SG24, whereas the most sensitive microorganism was C. neoformans. Compound 7 (MIC $=2-128 \mu \mathrm{g} / \mathrm{mL})$ was more active as compared with its precursors followed in a decreasing order by compound 4 (MIC $=4-256 \mu \mathrm{g} / \mathrm{mL})$, compound $\mathbf{6}(\mathrm{MIC}=8->256 \mu \mathrm{g} / \mathrm{mL})$, and compound $\mathbf{3}$ (MIC $=32->256 \mu \mathrm{g} / \mathrm{mL})$.

The lowest MIC value of $2 \mu \mathrm{g} / \mathrm{mL}$ was recorded on $S$. aureus with compound 7 , whereas the lowest MMC value of
$4 \mu \mathrm{g} / \mathrm{mL}$ was obtained on C. parapsilosis and C. neoformans with compound 7. However, the highest MIC value of $256 \mu \mathrm{g} / \mathrm{mL}$ was recorded on $V$. cholerae CO6 with compound 3 and on $V$. cholerae NB2 with compounds 4 and $\mathbf{6}$, while the highest MMC value of $256 \mu \mathrm{g} / \mathrm{mL}$ was obtained on $V$. cholerae SG24 with compound 7 and on C. parapsilosis, S. flexneri, E. coli, and B. subtilis with compound 3. A lower MBC/MIC $(\leq 4)$ value signifies that a minimum amount of compounds is used 
TABLE 2: Minimum inhibitory concentrations (MICs) and minimum microbicidal concentrations (MMCs) ( $\mu \mathrm{g} / \mathrm{ml})$ of compound 7 and its entire precursors against fungal and bacterial strains.

\begin{tabular}{|c|c|c|c|c|c|c|}
\hline Microorganisms & Inhibition parameters & 3 & 4 & 6 & 7 & Reference drugs ${ }^{*}$ \\
\hline \multicolumn{7}{|l|}{ Gram-positive bacteria } \\
\hline \multirow{2}{*}{ Bacillus subtilis } & MIC & 64 & 16 & 64 & 8 & 2 \\
\hline & $\mathrm{MBC}$ & 256 & 32 & $>256$ & 32 & 2 \\
\hline \multirow{2}{*}{ S. aureus } & MIC & 64 & 16 & 32 & 2 & 0.5 \\
\hline & $\mathrm{MBC}$ & $>256$ & 32 & 64 & 8 & 0.5 \\
\hline \multicolumn{7}{|l|}{ Gram-negative bacteria } \\
\hline \multirow{2}{*}{ E. coli $\mathrm{S} 2(1)$} & MIC & 64 & 32 & 32 & 8 & 2 \\
\hline & MBC & 256 & 64 & $>256$ & 32 & 2 \\
\hline \multirow{2}{*}{ S. flexneri } & MIC & 128 & 32 & 128 & 16 & 8 \\
\hline & $\mathrm{MBC}$ & 256 & $>256$ & $>256$ & 32 & 8 \\
\hline \multirow{2}{*}{ P. aeruginosa } & MIC & 128 & 16 & 128 & 8 & 4 \\
\hline & $\mathrm{MBC}$ & $>256$ & 32 & $>256$ & 32 & 4 \\
\hline \multirow{2}{*}{ V. cholerae NB2 } & MIC & $>256$ & 256 & 256 & 64 & 32 \\
\hline & $\mathrm{MBC}$ & nd & $>256$ & $>256$ & 128 & 32 \\
\hline \multirow{2}{*}{ V. cholerae SG24 } & MIC & $>256$ & $>256$ & $>256$ & 128 & 64 \\
\hline & $\mathrm{MBC}$ & nd & nd & nd & 256 & 64 \\
\hline \multirow{2}{*}{ V. cholerae CO6 } & MIC & 256 & 64 & $>256$ & 32 & 8 \\
\hline & $\mathrm{MBC}$ & $>256$ & 128 & nd & 64 & 8 \\
\hline \multicolumn{7}{|l|}{ Yeasts } \\
\hline \multirow{2}{*}{ C. parapsilosis ATCC22019 } & MIC & 64 & 4 & 32 & 4 & 2 \\
\hline & MFC & 256 & 8 & 64 & 4 & 2 \\
\hline \multirow{2}{*}{ C. albicans ATCC 9002} & MIC & 64 & 8 & 64 & 4 & 4 \\
\hline & MFC & $>256$ & 16 & 128 & 8 & 4 \\
\hline \multirow{2}{*}{ C. neoformans IP95026 } & MIC & 32 & 4 & 8 & 4 & 2 \\
\hline & MFC & 128 & 8 & 16 & 4 & 2 \\
\hline
\end{tabular}

${ }^{*}$ Ciprofloxacin for bacteria and nystatin for yeasts; nd: not determined; compounds 1, 2, and $\mathbf{5}$ were not tested.

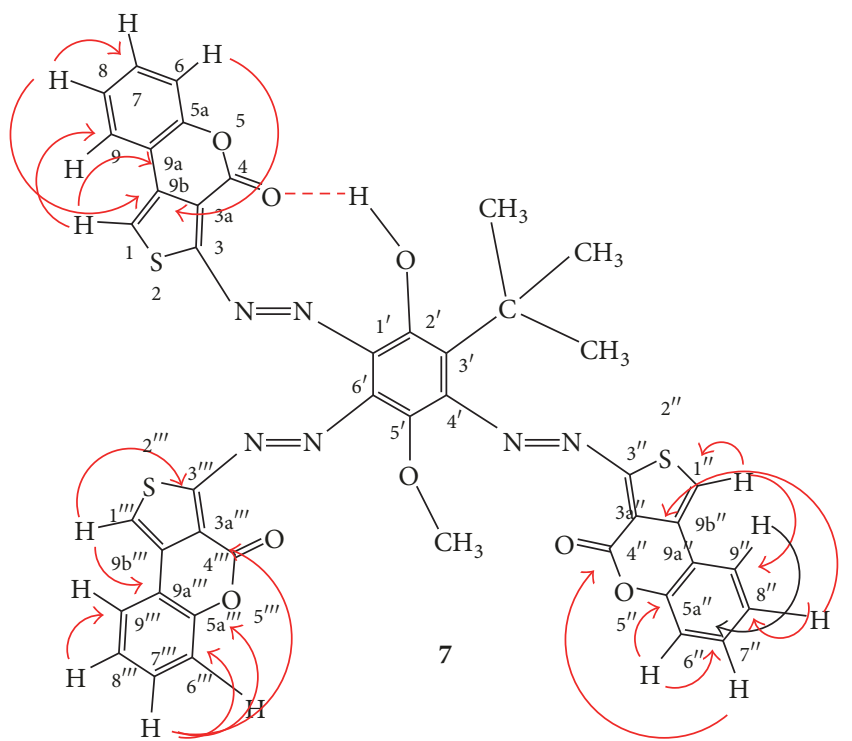

FIGURE 1: HMBC interactions in compound 7.

to kill the microbial species, whereas a higher value signifies the use of comparatively higher amounts of samples for the control of any microorganism [28].

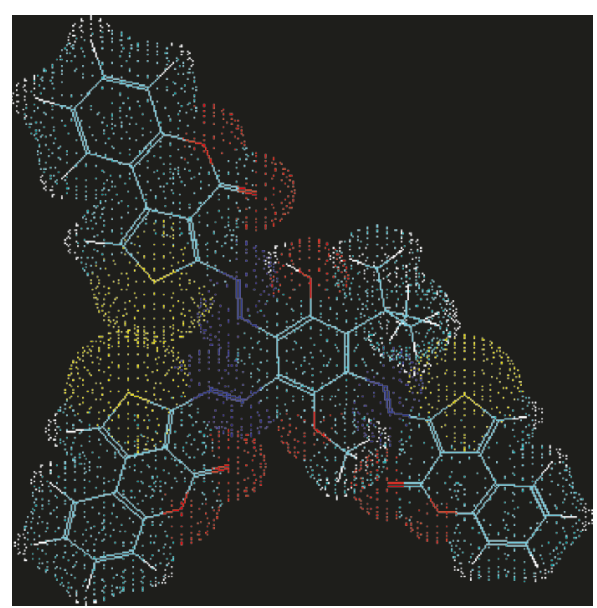

Figure 2: Optimized 3D view of compound 7. The structure was drawn with the program $\mathrm{ACD} / 3 \mathrm{D}$ viewer (freeware) of $\mathrm{ACD} / \mathrm{Labs}$.

The strains of $V$. cholerae NB2 and PC2 [21, 22] and Shigella flexneri [29] included in the present study were MDR clinical isolates and these were resistant to commonly used drugs such as ampicillin, streptomycin, tetracycline, nalidixic acid, furazolidone, and cotrimoxazole. However, 
these bacterial strains were found to be sensitive to most of the tested samples, suggesting that their administration may represent an alternative treatment against the diseases caused by these types of MDR pathogenic strains.

From the SAR point of view, we can say that compounds 4 and $\mathbf{6}$ are not microbicides for the bacterial strains $V$. cholerae NB2, S. flexneri, and V. cholerae SG24, with respect to the $\mathrm{MBC} / \mathrm{MIC}$ data displayed in Table 2 . In contrast, compound 7 is microbicidal for these bacterial strains. The improved antibacterial profiles of the hybrid compound could be due to the synergetic interactions of the primary potent pharmacophores combined in the single molecular platform. The cumulative effects of the three disazo scaffolds certainly contributed to a greater extent to shaping the global biological profile of the new hybrid molecule. These observations that corroborate recent findings from analogous investigation [18].

\section{Conclusion}

In summary, the diazotized title 2-aminothiophene derivative 5 is a powerful electrophilic reagent which attacks phenolic substrate $\mathbf{6}$ at all its three nonsubstituted ring positions to give with good yield the corresponding trisazo hybrid compound 7 whose structural assignment was done on the basis of the available analytic and spectroscopic data. The combination in a single molecular platform of the pharmacophores related to the phenolic, the three thienocoumarin, and the three disazo moieties resulted in a synergy of actions which globally contributed as initially anticipated to enhancing the antimicrobial activities of the reaction product 7 when compared with the profiles of the precursors 3, 4, and 6. The results showed that the diazotization followed by the coupling reaction increases the antimicrobial activity of the trisazo compound compared with that of the free 2 -aminothiophene and phenol. The overall results of this study indicated that compound 7 had the greatest potential value against both yeasts and multidrug-resistant bacteria, so further investigation is warranted.

\section{Conflicts of Interest}

The authors declare that there are no conflicts of interest regarding the publication of this paper.

\section{Authors' Contributions}

All authors equally contributed to the paper and have given approval to the final version of the paper.

\section{Acknowledgments}

Emmanuel Sopbué Fondjo gratefully acknowledges the financial support from DAAD (Grant no. A/09/07421) for a scholarship. Arnaud Djintchui Ngongang is grateful to his supervisors, Professors Dr. J. S. Glaser and Dr. R. Marx, for helpful suggestions in performing the NMR experiments. The necessary NMR spectrometers were provided by the Bavarian NMR Center (Bayerisches NMR-Zentrum). Additional financial supports for the work were obtained from the University of Dschang's research grant committee and the Cameroonian Ministry of Higher Education special research allocation. Professor Dr. Taoufik Rohand thanks Cadi Ayyad University and specially the Polydisciplinary Faculty of Safi for its professionalism.

\section{Supplementary Materials}

Figure 1: MS spectrum of compound 4. Figure 2: $1 \mathrm{H}-\mathrm{NMR}$ spectra of compound 4 (DMSO-d6, $250 \mathrm{MHz}$ ). Figure 3: 13C-NMR spectrum of compound 4 (DMSO-d6, 62.5 MHz). Figure 4: UV-visible spectrum of compound 7. Figure 5: IR spectrum of compound 7. Figure 6: full 1H-NMR spectrum of compound 7 (DMSO-d6, $250 \mathrm{MHz}$ ). Figure 7: expanded 1H-NMR spectrum of compound 7 (DMSO-d6, $250 \mathrm{MHz}$ ). Figure 8: 13C-NMR spectrum (aromatic region) of compound 7 (DMSO-d6, 62.5 MHz). Figure 9: full 13CNMR spectrum of compound 7 (DMSO-d6, $62.5 \mathrm{MHz}$ ). Figure 10: HMBC spectrum of compound 7 (DMSOd6, $62.5 \mathrm{MHz}$ ). Figure 11: MS spectrum of compound 7. (Supplementary Materials)

\section{References}

[1] C. E. Maddox, L. M. Laur, and L. Tian, "Antibacterial activity of phenolic compounds against the phytopathogen Xylella fastidiosa," Current Microbiology, vol. 60, no. 1, pp. 53-58, 2010.

[2] A.-M. Boudet, "Evolution and current status of research in phenolic compounds," Phytochemistry, vol. 68, no. 22-24, pp. 2722-2735, 2007.

[3] G. C. Fraga, Plant Phenolics And Human Health: Biochemistry, Nutrition And Pharmacology, John Whiley \& Sons, NJ, USA, 2010.

[4] H. M. Mohamed, A. H. F. A. El-Wahab, A. M. El-Agrody et al., "Synthesis and characterization of new diiodocoumarin derivatives with promising antimicrobial activities," Beilstein Journal of Organic Chemistry, vol. 7, pp. 1688-1696, 2011.

[5] A. M. El-Agrody, M. S. Abd El-Latif, N. A. El-Hady, A. H. Fakery, and A. H. Bedair, "Heteroaromatization with 4Hydroxycoumarin Part II: Synthesis of some new pyrano[2,3d]pyrimidines, [1,2,4] triazolo[1,5-c]pyrimidines and pyrimido[1,6-b]-[1,2,4] triazine derivatives," Molecules, vol. 6, no. 6, pp. 519-527, 2001.

[6] U. S. Weber, B. Steffen, and C.-P. Siegers, "Antitumor-activities of coumarin, 7-hydroxy-coumarin and its glucuronide in several human tumor cell lines," Research Communications in Molecular Pathology and Pharmacology, vol. 99, no. 2, pp. 193206, 1998.

[7] P. S. Fogue, P. K. Lunga, E. S. Fondjo et al., "Substituted 2aminothiophenes: Antifungal activities and effect on Microsporum gypseum protein profile," Mycoses, vol. 55, no. 4, pp. 310317, 2012.

[8] R. W. Sabnis, D. W. Rangnekar, and N. D. Sonawane, "2aminothiophenes by the gewald reaction," Journal of Heterocyclic Chemistry, vol. 36, no. 2, pp. 333-345, 1999.

[9] F. J. B. Mendonça Junior, R. G. Lima-Neto, T. B. de Oliveira et al., "Synthesis and evaluation of the antifungal activity of 2-(substituted-amino)-4,5-dialkyl-thiophene-3-carbonitrile 
derivatives," Latin American Journal of Pharmacy, vol. 30, no. 8, pp. 1492-1499, 2011.

[10] H. Gershon and L. Shanks, "Fungitoxicity of 1,4 naphthoquinones to Candida albicans and Trichophyton mentagrophytes," Canadian Journal of Microbiology, vol. 21, no. 9, pp. 1317-1321, 1975.

[11] F. C. de Abreu, P. A. L. De Ferraz, and M. O. F. Goulart, "Some applications of electrochemistry in biomedical chemistry. Emphasis on the correlation of electrochemical and bioactive properties," Journal of the Brazilian Chemical Society, vol. 13, no. 1, pp. 19-35, 2002.

[12] E. S. Fondjo, J. Tsemeugne, J. De Dieu Tamokou, A. N. Djintchui, J. R. Kuiate, and B. L. Sondengam, "Synthesis and antimicrobial activities of some novel thiophene containing azo compounds," Heterocyclic Communications, vol. 19, no. 4, pp. 253-259, 2013.

[13] J. Tamokou, J. Tsemeugne, F. E. Sopbué et al., "Antibacterial and cytotoxic activities and SAR of some Azo compounds containing thiophene backbone," Pharmacologia, vol. 7, no. 4, pp. 182-192, 2016.

[14] H. E. Gaffer, M. M. G. Fouda, and M. E. Khalifa, "Synthesis of some novel 2-amino-5-arylazothiazole disperse dyes for dyeing polyester fabrics and their antimicrobial activity," Molecules, vol. 21, no. 1, article no. 122, 2016.

[15] S. W. Collier, J. E. Storm, and R. L. Bronaugh, "Reduction of azo dyes during in vitro percutaneous absorption," Toxicology and Applied Pharmacology, vol. 118, no. 1, pp. 73-79, 1993.

[16] R. Benigni and L. Passerini, "Carcinogenicity of the aromatic amines: From structure-activity relationships to mechanisms of action and risk assessment," Mutation Research - Reviews in Mutation Research, vol. 511, no. 3, pp. 191-206, 2002.

[17] D. Brown and P. Laboureur, "The degradation of dyestuffs: Part I Primary biodegradation under anaerobic conditions," Chemosphere, vol. 12, no. 3, pp. 397-404, 1983.

[18] V. Mkpenie, G. Ebong, I. B. Obot, and B. Abasiekong, "Evaluation of the effect of azo group on the biological activity of 1(4-Methylphenylazo)-2-naphthol," E-Journal of Chemistry, vol. 5, no. 3, pp. 431-434, 2008.

[19] E. Sopbué Fondjo, D. Döpp, and G. Henkel, "Reactions of some anellated 2-aminothiophenes with electron poor acetylenes," Tetrahedron, vol. 62, no. 29, pp. 7121-7131, 2006.

[20] J. Tsemeugne, F. E. Sopbué, D. A. Ngongang, R. W. Sabnis, and B. L. Sondengam, "Coupling of the diazonium sulphate of 3-amino-4H-benzo[f]thieno[3, 4-c] $(2 \mathrm{H})$ chromen-4-one with phenol and naphthol derivatives in varied stoichiometries," Trends in Organic Chemistry, vol. 18, pp. 55-69, 2017.

[21] P. K. Bag, P. Bhowmik, T. K. Hajra et al., "Putative virulence traits and pathogenicity of Vibrio cholerae non-O1, non-O139 isolates from surface waters in Kolkata, India," Applied and Environmental Microbiology, vol. 74, no. 18, pp. 5635-5644, 2008.

[22] P. Thakurta, P. Bhowmik, S. Mukherjee, T. K. Hajra, A. Patra, and P. K. Bag, "Antibacterial, antisecretory and antihemorrhagic activity of Azadirachta indica used to treat cholera and diarrhea in India," Journal of Ethnopharmacology, vol. 111, no. 3, pp. 607612, 2007.

[23] A. L. Ngankeu Pagning, J.-D. Tamokou, M. Lateef et al., "New triterpene and new flavone glucoside from Rhynchospora corymbosa (Cyperaceae) with their antimicrobial, tyrosinase and butyrylcholinesterase inhibitory activities," Phytochemistry Letters, vol. 16, pp. 121-128, 2016.
[24] K. Gewald, "Zur Reaktion von --Oxo-mercaptanen mit Nitrilen," Angewandte Chemie, vol. 73, no. 3, pp. 114-114, 1961.

[25] K. Gewald, "Heterocyclen aus CH-aciden Nitrilen, VII. 2-Amino-thiophene aus $\alpha$-Oxo-mercaptanen und methylenaktiven Nitrilen," Chemische Berichte, vol. 98, no. 11, pp. 3571-3577, 1965.

[26] W. Ried and E. Nyiondi-Bonguen, "Über die gemeinsame Einwirkung von Schwefel und methylenaktiven Nitrilen oder Ammoniak auf 2-Hydroxyacetophenon," Justus Liebigs Annalen der Chemie, vol. 1973, no. 1, pp. 134-140, 1973.

[27] Attar-ur-Rahman and Choudhary I. M., "Chapter 7: Recent developments in NMR spectroscopy. Solving problems with NMR spectroscopy," in Chapter 7: Recent Developments in NMR Spectroscopy. Solving Problems with NMR Spectroscopy, pp. 376377, Academic Press, Inc., San Diego, Calif, USA, 1996.

[28] M. G. Djouossi, J.-D. Tamokou, D. Ngnokam et al., "Antimicrobial and antioxidant flavonoids from the leaves of Oncoba spinosa Forssk. (Salicaceae)," BMC Complementary and Alternative Medicine, vol. 15, no. 1, article no. 134, 2015.

[29] S. Acharyya, P. Sarkar, D. R. Saha, A. Patra, T. Ramamurthy, and P. K. Bag, "Intracellular and membrane-damaging activities of methyl gallate isolated from Terminalia chebula against multidrug-resistant Shigella spp," Journal of Medical Microbiology, vol. 64, article 000107, no. 8, pp. 901-909, 2015. 

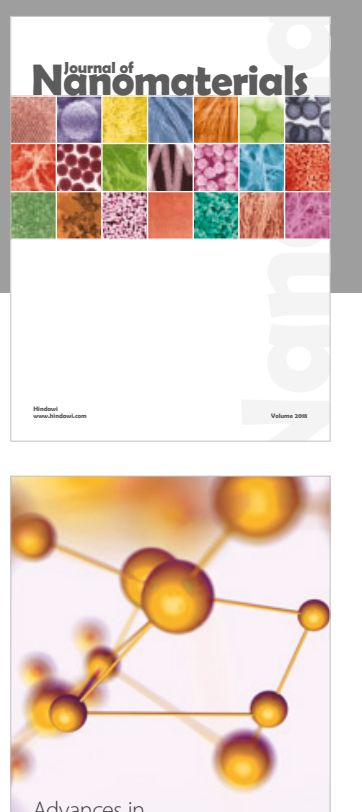

Physical Chemistry
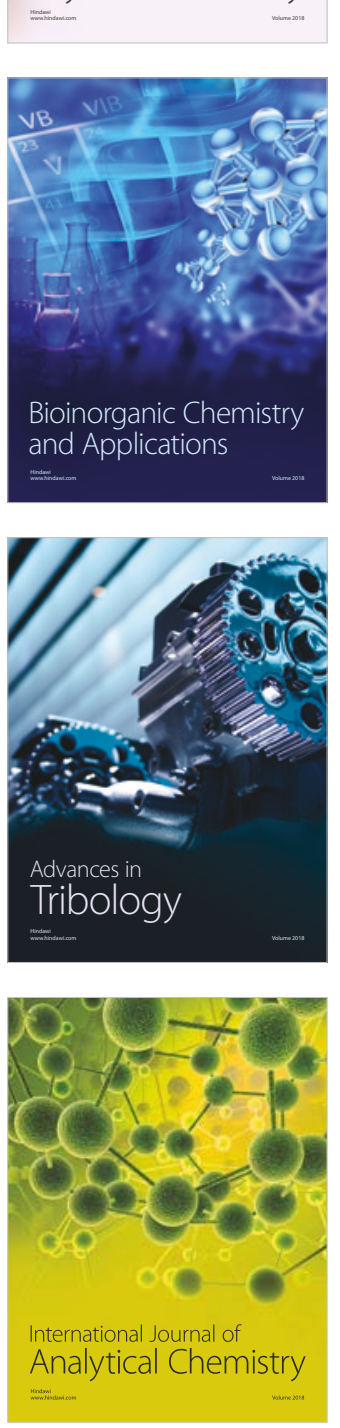

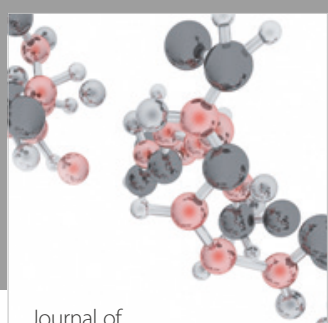

Analytical Methods

in Chemistry

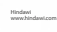

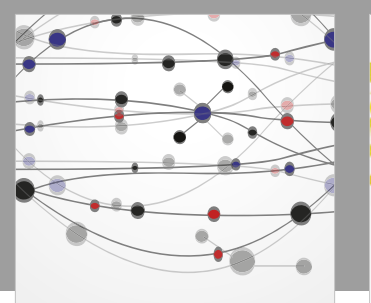

The Scientific World Journal

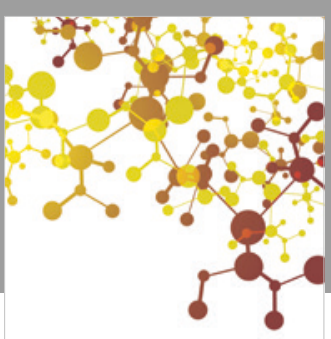

Journal of

Applied Chemistry
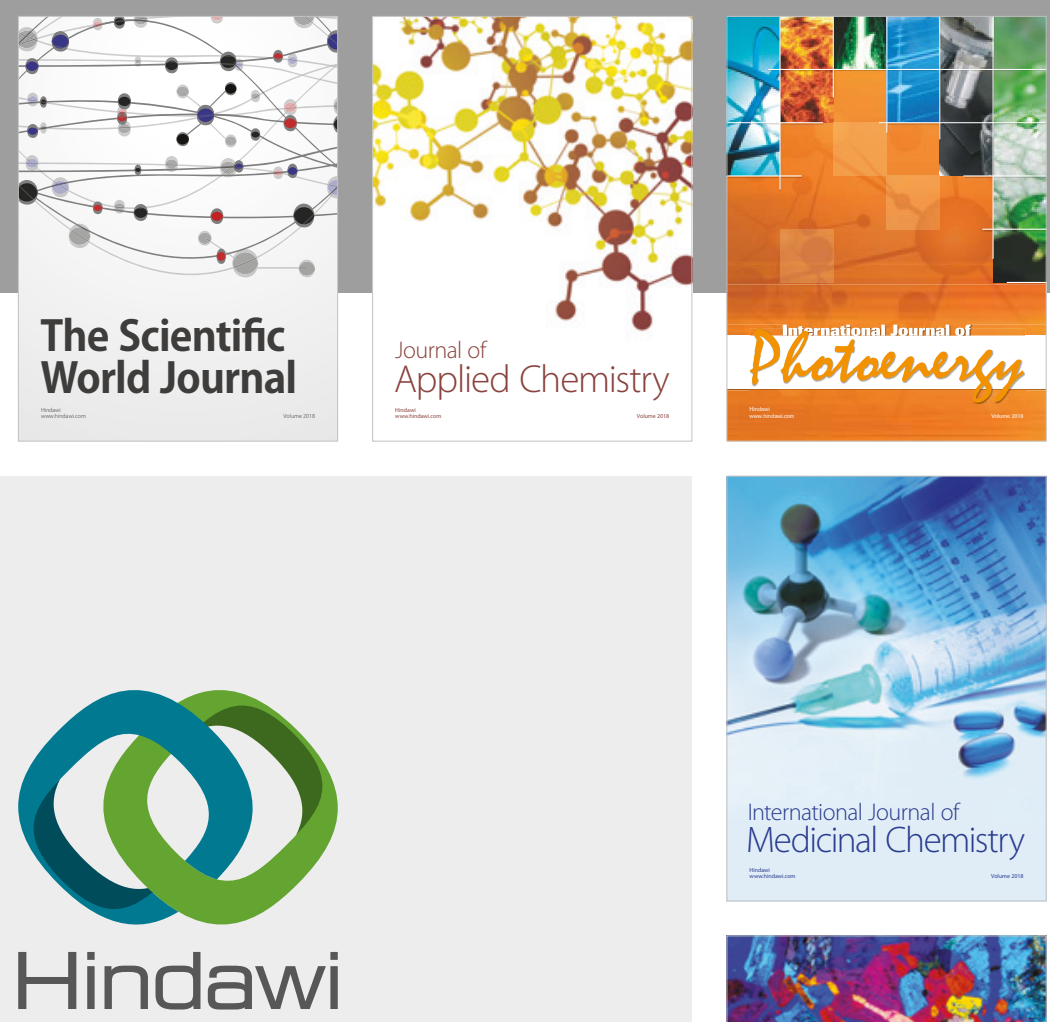

Submit your manuscripts at

www.hindawi.com
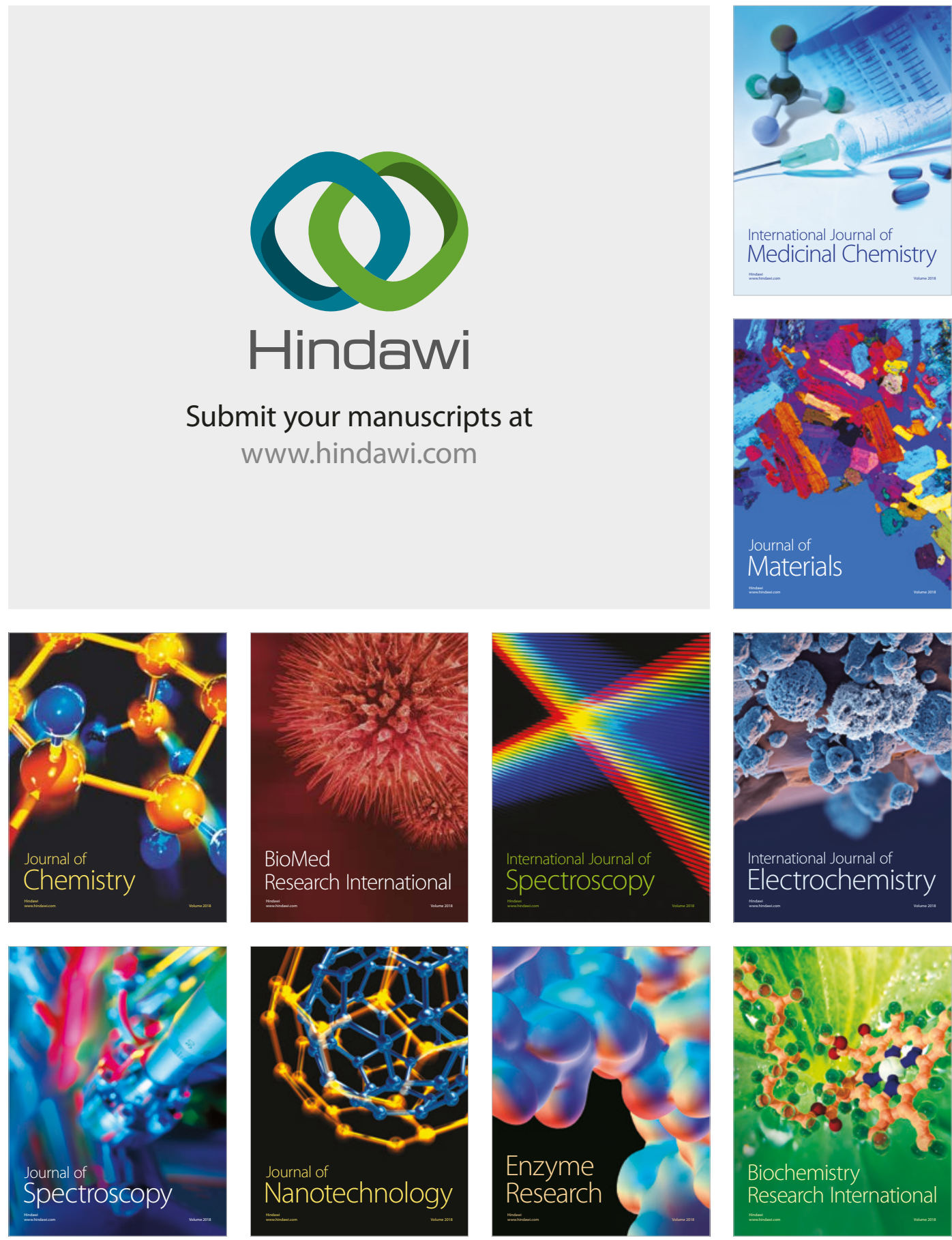
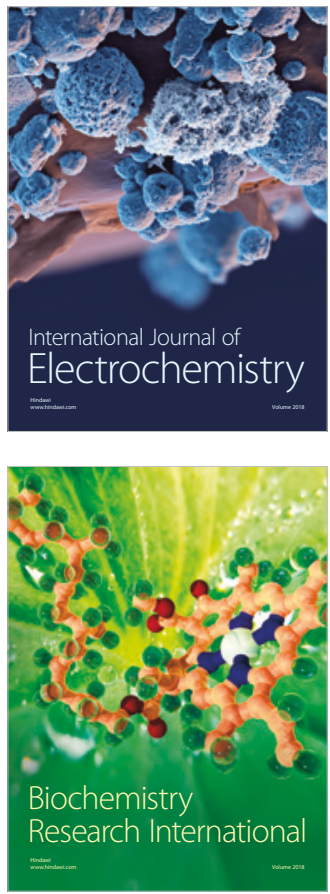